\title{
NILAI-NILAI AKHLAK DALAM \\ KOMUNIKASI EDUKATIF AYAH-ANAK DI DALAM AL-QURAN (Studi Tematis Terhadap Kisah Āzar-Nabi Ibrāhīm, Nabi Ibrāhīm- Nabi Ismā'il, Nabi Ya'qūb-Nabi Yūsuf)
}

\author{
Fitri Hardiyanti, ${ }^{*}$ \\ Aam Abdussalam, Elan Sumarna \\ Program Studi Ilmu Pendidikan Agama Islam, \\ Fakultas Pendidikan Ilmu Pengetahuan Sosial, Universitas Pendidikan Indonesia \\ *Email: mpithardiyanti@gmail.com
}

\begin{abstract}
ABSTRAK
Penelitian ini dilatarbelakangi oleh dekadensi moral pada anak muda zaman sekarang khususnya terkait akhlak anak terhadap orang tua. Pendidikan informal dalam keluarga yang tidak sesuai dengan ajaran Islam mengakibatkan hal tersebut terjadi. Dalam penelitian ini akan dibahas tentang penanaman nilai-nilai akhlak dalam komunikasi ayah-anak di dalam alQur`ān. Penelitian ini bertujuan untuk mengetahui komunikasi dan nilai-nilai akhlak dari kisah Azar-Nabi Ibrāhim, Nabi Ibrāhim-Ismā'il, Nabi Ya'qūb-Yūsuf dan implikasinya dalam pembelajaran PAI. Pendekatan penelitian yang digunakan adalah pendekatan kualitatif. Adapun metode yang digunakan adalah metode tafsir maudu' $i$, teknik pengumpulan data yang dipergunakan dalam penelitian ini adalah studi pustaka. Adapun teknik analisis data

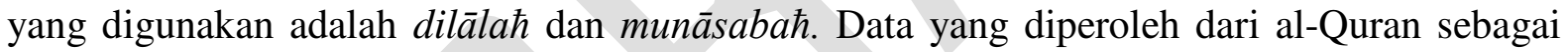
sumber utama juga dilengkapi dengan tafsir lainnya beserta buku-buku yang ada relevansinya dengan masalah penelitian sebagai sumber sekunder. Dari hasil penelitian ditemukan komunikasi yang ideal dalam kisah Nabi Ibrāhim-Ismā'il dan Nabi Ya'qūb-Yūsuf karena keduanya memiliki kesamaan iman sehingga dapat mewujudkan komunikasi yang efektif. Keduanya mendiskusikan suatu permasalahan dan meminta pendapat lawan bicara sehingga terdapat keterbukaan pikiran dan perasaan. Adapun komunikasi antara Nabi Ibrāhim dengan azar menjadi suatu pembelajaran bagi seorang anak dalam menghadapi orang tua yang kafir, bentuk komunikasi Nabi Ibrāhim kepada ayahnya berupa seruan kebaikan, mengingatkan pada kebenaran dan menasehati dengan penuh kelembutan. Dalam penelitian ini juga ditemukan nilai-nilai akhlak dalam komunikasi tersebut di antaranya akhlak kepada Allah dan akhlak kepada manusia. Implikasi kajian ini bagi pembelajaran PAI sebagai pengembangan komunikasi edukatif di antaranya: prinsip kasih-sayang, prinsip ketulusan, dan prinsip komunikasi verbal (Qaulan sadidan, Qaulan layyinan, Qaulan ma'rufan dan Qaulan kariman); dan pengembangan sistem instruksional pembelajaran, di antaranya perlu: metode pembelajaran edukatif, guru sebagai role model, dan interaksi pembelajaran intrapersonal-interpersonal.
\end{abstract}

Kata Kunci: Dekadensi moral, Nilai-nilai akhlak, Komunikasi, Pembelajaran PAI 


\section{PENDAHULUAN}

Al-Quran diyakini oleh umat Islam sebagai kalāmulláh (firman Allah) yang mutlak benar, berlaku sepanjang zaman, dan mengandung ajaran juga petunjuk tentang berbagai hal yang berkaitan dengan segala kehidupan. (Nata, 2009, hal. 1). Salah satu isi kandungan al-Quran yaitu berbicara mengenai akhlak, firman Allah swt. dalam al-Quran surat $a l-A h z \bar{a} b$ [33] 21:

立Artinya: "Sesungguhnya telah ada pada (diri) Rasūlulláh itu suri teladan yang baik bagimu (yaitu) bagi orang yang mengharap (rahmat) Allah dan (kedatangan) hari kiamat dan Dia banyak menyebut Allah." (QS. Al-Ahzāb [33]: 21)

Rasulullah saw. telah diutus oleh Allah untuk menyempurnakan akhlak namun tidak menutup kemungkinan banyak muslim saat ini yang berakhlak buruk, khususnya bagi para remaja saat ini yang telah terpengaruhi arus mode di era modern ini. Turunnya moral remaja saat ini telah menimbulkan sikap pembangkangan diri terhadap orang tua dikarenakan keinginannya yang mengikuti zaman akan tetapi orang tua tidak mampu mengikuti kehidupan anaknya yang mengikuti arus mode saat ini. pada akhirnya pemberontakan pun terjadi sehingga dapat memutus hubungan serta interaksi yang terjalin antara orang tua dengan anak.

Al-Quran memerintahkan kita untuk berbuat baik kepada orang tua dari perilaku, sikap dan tutur kata namun sekarang ini banyak kasus berkenaan dengan kedurhakaan anak terhadap orang tuanya. Durhakanya anak terhadap orang tuanya merupakan masalah yang harus ditangani serius. Namun turunnya moral anak-anak pada saat ini tentunya disebabkan oleh beberapa faktor terutama faktor lingkungan. Hal seperti ini menjadi tanggung jawab orang tua karena orang tua merupakan pendidik pertama bagi anakanak mereka.
Salah satu alternatif yang bisa menjadi solusi penanaman akhlak mulia pada diri seseorang adalah melalui pendidikan informal. Sebagaimana yang diketahui bahwa pendidikan informal merupakan pendidikan pertama yang diperoleh setiap individu yakni dalam lingkungan keluarga. Hal ini sejalan dengan pendapat yang dikemukakan oleh Jalaluddin (2011, hal. 294) yang menyebutkan bahwa "Keluarga menurut para pendidik merupakan lapangan pendidikan yang pertama dan pendidiknya adalah kedua orang tua”.

Untuk dapat menjalin hubungan yang harmonis antara orang tua dan anak perlu dibangun komunikasi dan interaksi yang baik di dalam keluarga, sehingga dari komunikasi yang baik orang tua dapat menanamkan dan membiasakan akhlak mulia pada anak-anak.

Agus M. Hardjana (dalam Naim, 2011, hal. 18) mengungkapkan bahwa komunikasi dapat didefinisikan sebagai proses penyampaian makna dalam bentuk gagasan atau informasi dari seseorang kepada orang lain melalui media tertentu, karena pertukaran makna merupakan inti yang terdalam kegiatan komunikasi.

Lewat pesan-pesan yang disampaikan melalui komunikasi tersebut dapat menanamkan nilai-nilai ajaran Islam termasuk pembiasaan akhlak yang mulia.

Dalam hal ini al-Quran mampu memberikan solusi terhadap segala permasalahan, salah satunya melalui kisahkisah Nabi di dalam al-Quran yang memberikan pelajaran kepada umat manusia. Seperti yang dikemukakan oleh Syahidin (2009, hal. 99) "kisah termasuk salah satu bentuk sastra yang menarik perhatian para pendengar dan banyak mengandung pelajaran guna memantapkan pesan-pesan yang dikandungnya ke dalam jiwa".

Melalui kisah-kisah dalam alQuran memiliki fungsi yang edukatif dan sangat berguna dalam proses penanaman nilai-nilai akhlak. lewat kisah Azar- Nabi 
Ibrāhim, Nabi Ibrāhim-Ismā'il, Nabi Ya'qūb-Yūsuf dapat dijadikan teladan untuk membangun komunikasi yang baik antara orang tua-anak begitupun sebaliknya sehingga penanaman nilai-nilai akhlak dapat diterapkan melalui komunikasi yang baik.

\section{METODE}

Pada penelitian pustaka ini menggunakan pendekatan penelitian, jenis pendekatan penelitian ini menggunakan salah satu jenis pendekatan yaitu jenis penelitian kualitatif. Menurut Sukmadinata (2013, hal. 60) penelitian kualitatif (Qualitative research) adalah suatu penelitian yang ditujukan untuk mendeskripsikan dan menganalisis fenomena, peristiwa, aktivitas sosial, sikap, kepercayaan, persepsi, pemikiran orang secara individual maupun kelompok. Dalam penelitian ini, pendekatan kualitatif digunakan untuk mendeskripsikan dan menganalisis tentang nilai-nilai akhlak dalam komunikasi ayah-anak dalam alQuran sehingga peneliti memperoleh informasi secara lengkap dan mendalam , untuk memperoleh informasi yang lengkap dan mendalam penelitian ini menggunakan metode penelitian deskriptif dan metode maudū'i.

Secara konseptual penelitian ini menggunakan metode deskriptif Penelitian deskriptif adalah penelitian yang bermaksud untuk membuat gambaran mengenai situasi-situasi atau kejadiankejadian dan mengakumulasikan data dasar dalam cara deskriptif (Suryabrata, 2012, hal. 76). Sedangkan dalam pelaksanaanya, penelitian ini menggunakan metode tafsir maudī'i, metode tafsir maudū'i yaitu menjelaskan konsep al-Quran tentang suatu masalah/tema tertentu dengan cara menghimpun seluruh ayat al-Quran yang membicarakan tema tersebut. kemudian ayat-ayat tersebut dikaji secara komprehensif, mendalam, dan tuntas dari berbagai aspek kajiannya. Baik dari segi asbāb al-Nuzūl nya, munāsabaћ nya, makna kosa katanya dll (Hermawan, 2011, hal. 118). Jadi, metode merupakan suatu sarana yang sangat penting dalam suatu penelitian. Dan dalam penelitian ini digunakan untuk mengetahui nilai-nilai akhlak dalam komunikasi ayah-anak di dalam al-Quran.

Dalam penelitian kualitatif ini yang menjadi isntrumen atau alat penelitian adalah peneliti itu sendiri, peneliti kualitatif sebagai human instrument, berfungsi menetapkan fokus penelitian, memilih informan sebagai sumber data, melakukan pengumpulan data, menilai kualitas data, analisis data, menafsirkan data dan membuat kesimpulan atas semuanya (Sugiyono, 2013, hal. 306).Maka dari itu dalam penelitian ini, yang menjadi isntrumennya ialah peneliti sendiri. Peneliti memulai kajian dengan mencari ayat-ayat yang berkaitan dengan komunikasi ayah-anak di dalam al-Quran. Al-Quran sendiri pun menjadi sumber utama dan juga kitab-kitab tafsir, dalam penelitian ini juga buku-buku yang relevan dengan pembahasan penelitian menjadi sumber penunjangnya.

Sumber data yang digunakan dalam penelitian ini menggunakan sumber data primer dan sekunder, sumber data primer penelitian ini menggunakan alQuran, adapun ayat-ayat yang berkaitan dalam penelitian ini adalah Q.S. al-An' $\bar{a} m$ : [6] 74, Q.S. Maryam [19] 42-48, Q.S. alȘäffāt [37] 102, Q.S. Yūsuf [12] 4-5, Q.S. Yūsuf [12] 100. Selain al-Quran adapula tafsir-tafsir yang digunakan sebagai sumber data primer dalam penelitian ini yaitu diantaranya:Tafsir Al-Misbāh,Tafsir $A l-A z h \bar{a} r$, dan Tafsir An-Nūr. Adapun data sekunder dalam penelitian ini semua bukubuku yang relevan dengan permasalahan penelitian sebagai penunjang, data sekunder ini berfungsi sebagai pelengkap dari sumber data primer.

Teknik pengumpulan data yang digunakan dalam penelitian ini adalah studi kepustakaan dan studi dokumentasi, Data-data yang terkumpul dalam 
penelitian ini yang berbentuk catatan atau dokumentasi yang di ambil dari sumber primer yaitu al-Quran dan kitab-kitab tafsir juga sumber lainnya seperti buku-buku yang berkaitan dengan pembahasan yaitu Nilai-Nilai Akhlak Dalam Komunikasi Ayah-Anak di Dalam al-Quran.

Selanjutnya tahapan analisis data dalam penelitian ini ialah menganalisis kandungan ayat-ayat yang sudah dipilih dan berkaitan dengan pembahasan, ayat tersebut meliputi: Q.S. al-An'ām: [6] 74, Q.S. Maryam [19] 42-48, Q.S. al-Säffāt [37] 102, Q.S. Yūsuf [12] 4-5, Q.S. Yūsuf [12] 100. Dalam melakukan analisis data terdapat langkah-langkah yang harus dilaksanakan dalam melakukan analisis data menurut Sugiyono (2013, hal. 338$345)$ terdapat tiga langkah dalam menganalisis data diantaranya: 1 . Reduksi data, 2. Penyajian data, 3. Verification. Jadi, analisis dalam penelitian ini pertama peneliti merangkum dan memilih hal-hal yang pokoknya saja karena data yang diperoleh masih tercampur aduk, data yang diperoleh didapat dari sumber utama yaitu al-Quran dan kitab-kitab tafsir yang didapat melalui teknik pengumpulan data. Selanjutnya peneliti menganalisis ayatayat tersebut sesuai dengan penafsiran tafsir-tafsir al-Quran dengan menggunakan kitab-kitab tafsir yakni tafsir Al-Miṣbāh, tafsir Al-Azhār, dan tafsir An-Nūr. Selain itu peneliti pun membutuhkan kaidahkaidah yakni kaidah dilālah dan kaidah munāsabaћ.

Dilālah artinya memahami sesuatu dari sesuatu yang lain, sesuatu yang pertama disebut al-Madlūl dan segala sesuatu yang kedua disebut al-dall (petunjuk, penerang atau yang memberi dalil) (Yusuf, 2012, hal. 96).Sedangkan munāsabaћ secara bahasa berarti keserasian dan kedekatan. Hubungan tersebut dapat berbentuk keterkaitan makna anatara ayat atau surah. Makna tersebut dapat dipahami, bahwa apabila suatu ayat atau surah sulit ditangkap maknanya secara utuh, maka menurut metode munasabah ini mungkin dapat dicari penjelasannya di ayat atau di surat lain yang mempunyai kesamaan atau kemiripan (Anwar, 2009, hal. 61).

Setelah peneliti mereduksi dan menyajikan data dalam bentuk deskripsi selanjutnya peneliti mulai menyimpulkan hasil penelitian untuk menjawab pertanyaan dari rumusah masalah penelitian ini.

\section{HASIL DAN PEMBAHASAN}

1. Komunikasi Ayah-Anak dalam al-
Quran

a. Kisah Azar- Nabi Ibrāhim

Shihab (2008.a.IV, hal. 158) menyatakan dalam Q.S. al-An'ām [6]: 74 dan ayat-ayat lainnya menguraikan sekeluit pengalaman Nabi Ibrāhim dalam "menemukan" Allah swt., Tuhan Yang Maha Esa, serta bantahan beliau terhadap kaum musyrikin yang mempertuhankan bintang-bintang dan membuat serta mengadakan untuk setiap bintang yang mereka puja masing-masing satu berhala. Dalam kandungan Q.S. al-An'ām [6]: 74 dan Q.S. Maryam [19]: 42-48 berisikan sebuah komunikasi antara seorang anak dengan ayah yaitu Nabi Ibrāhim dengan ayahnya Azar yang membahas suatu permasalahan ketauhidan. Bentuk komunikasi yang dicontohkan oleh Nabi Ibrāhim yang menghadapi ayahnya yang musyrik dan selalu menjadikan berhalaberhala sebagai tuhan-tuhannya,dan kisah ini dapat menjadi teladan bagi seorang anak ketika menghadapi orang tua yang kafir yakni:

1) Mengingatkan Kepada Kebenaran

Dalam QS. al-An'ām [6]: 74 dijelaskan bagaimana sikap seorang Nabi dalam menghadapi orang tuanya yang musyrik, sikap ayahnya yang selalu menyembah berhala sebagai tuhannya beliau menyampaikan suatu kebenaran lewat pertanyaan yang disampaikan yakni:

"Pantaskah kamu menjadikan berhalaberhala sebagai tuhan-tuhan? Sesungguhnya aku melihat kamu dan 
kaummu dalam kesesatan yang nyata." QS. al-An'ām [6]: 74

Shihab (2008.a.IV, hal. 161) menyatakan bahwa kalimat yang disampaikan Nabi Ibrāhim kepada ayahnya merupakan kalimat yang tegas karena masalah yang didiskusikan Nabi Ibrāhim adalah persoalan akidah yang merupakan persoalan prinsip sehingga membutuhkan ketegasan dalam bersikap dan bertindak.

Nabi Ibrāhim mengingatkan suatu kebenaran kepada ayahnya melalui pertanyaan hal ini sesuai dengan pendapat Gunara (2009, hal. 112) yang menyatakan ada 3 jenis metode bertanya yang dilakukan Rasūlulláh saw., salah satunya yaitu metode bertanya untuk menerangkan sesuatu kepada orang-orang kafir. Dengan metode ini, Rasülulláh saw., memberikan pertanyaan-pertanyaan kepada lawan bicara yang mempunyai jawaban yang sudah pasti (jawaban yang sudah diketahui oleh kedua belah pihak). Inti dari bertanya Rasul di sini adalah bukan ingin mencari jawabannya karena beliau sudah mengetahui jawabannya, melainkan semata-mata ingin membuat ragu (sadar) terhadap kekafiran atau perbuatan maksiat yang dilakukan oleh lawan bicaranya.

Jadi, bentuk komunikasi Nabi Ibrāhim ketika berbicara kepada ayahnya yang kafir beliau mengingatkan sebuah kebenaran, yakni perihal tuhan yang patut disembah. Tidak mungkin seorang hamba menciptakan tuhannya karena semestinya Tuhan lah yang menciptakan makhluknya. Namun cara beliau mengingatkan ayahnya yang kafir tersebut dengan menggunakan pertanyaan yang semata-mata untuk membuat ragu ayahnya.

Q.S. Maryam [19]: 42 serupa dengan Q.S. al-An'ām [6]: 74 yang mengingatkan kepada kebanaran melalui pertanyaan,

"ingatlah ketika ia berkata kepada bapaknya; "Wahai bapakku, mengapa kamu menyembah sesuatu yang tidak mendengar, tidak melihat dan tidak dapat menolong kamu sedikitpun?" (Q.S. Maryam [19] : 42)

Ash-Shiddieqy (2000.b.III, hal. 2481) menyatakan ketika menghadapi ayahnya beliau menanyakan terlebih dahulu rahasia dari menyembah batu, ibadat adalah suatu penta'zhiman (pengagungan, penghormatan) dan pentaqdisan (penyucian, pemuliaan) kedua hal tersebut tidak layak dilakukan terhadap makhluk. Nabi Ibrāhim bertanya demikian untuk menanamkan keragu-raguan dalam pikiran ayahnya dan mengajak ayahnya berpikir lebih lanjut mengenai kebenaran akidah.

2) Menyeru Kebaikan

Artinya:"Wahai bapakku, Sesungguhnya telah datang kepadaku sebahagian ilmu pengetahuan yang tidak datang kepadamu, Maka ikutilah Aku, niscaya aku akan menunjukkan kepadamu jalan yang lurus." (Q.S. Maryam [19]: 43).

Makna Q.S. Maryam [19]: 43 menjelaskan tentang proses dakwah Nabi Ibrāhim dengan ayahnya melalui komunikasi. Bentuk komunikasi yang dilakukan Nabi Ibrāhim berupa ajakan/seruan dalam kebaikan. Dalam

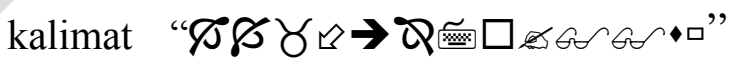
ini adalah kalimat fi'il Amr, dan ketentuan dari fi'il Amr ini adalah fi'il (kata kerja) yang menunjukkan suatu perintah atau ajakan. Dalam potongan ayat

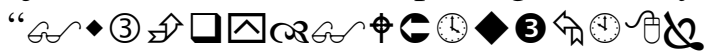

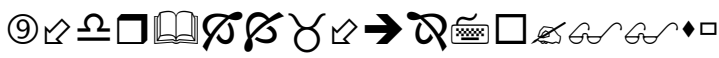
"Hal tersebut memberikan suatu isyarat bahwa Nabi Ibrāhim mengajak ayahnya untuk ikut dengannya ke jalan yang lurus.

Hal di atas sesuai dengan pendapat Enjang \& Tajiri(2009.b, hal. 11) bahwa kegiatan dakwah ini merupakan proses mengajak manusia kepada al-Islam yang dilakukan dengan lisan atau tulisan (dakwah bi al-lisān dan bi al-qalām), juga bisa dengan perbuatan (dakwah bi al-hāl). Sebagaimana yang dijelaskan dalam firman Allah swt. 
Artinya:"dan hendaklah ada di antara kamu segolongan umat yang menyeru kepada kebajikan, menyuruh kepada yang ma'ruf dan mencegah dari yang munkar merekalah orang-orang yang beruntung." (Q.S. al-'Imrān [3]: 104)

\section{3) Menasehati}

¿Artinya:"Wahai bapakku, janganlah kamu menyembah syaitan. Sesungguhnya syaitan itu durhaka kepada Tuhan yang Maha Pemurah.” (Q.S. Maryam [19]: 44).

Dalam ayat tersebut Nabi Ibrāhim memberikan nasihat dalam bentuk peringatan yaitu perintah larangan kepada ayahnya untuk tidak menyembah atau mengikuti kehendak syaitan agar terhindar dari azab dan siksaan Allah swt., analisis nya dalam Q.S. Maryam [19]: 44 ialah terdapat

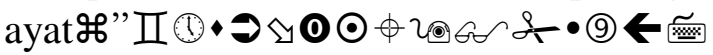
$\checkmark \rightarrow \bullet \cdot$ "kalimat tersebut merupakan perintah larangan, kalimat itu merupakan perintah langsung dan itu ditujukan untuk lawan bicara yang ada di depan kita sebagai pemberi perintah. Kata “"(tidak)menunjukkan suatu perintah, lalu diikuti fi'il mud̄āri"“(9) kalimat tersebut berubah menjadi Fi'il nahyi (kata kerja perintah) yang merupakan bentuk negatif dari fi'il Amr.

Dalam dakwah yang disampaikan Nabi Ibrāhim melalui komunikasi dengan ayahnya, Nabi Ibrāhim menggunakan

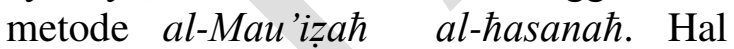
tersebut sesuai dengan pendapat Saputra

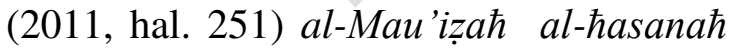
dapatlah diartikan sebagai ungkapan yang mengandung unsur bimbingan, pendidikan, pengajaran, kisah-kisah, berita gembira, peringatan, pesan-pesan positif (wasyiat) yang bisa dijadikan pedoman dalam kehidupan agar mendapatkan keselamatan dunia dan akhirat.

Dalam Q.S. Maryam [19]: 44 Nabi Ibrāhim memberikan nasihat kepada ayahnya dalam bentuk Tanżir yaitu suatu peringatan, agar ayahnya tidak menyembah berhala-berhala. Hal tersebut sesuai dengan pendapat Munir (2009, hal. 263) Tanżir adalah penyampaian pesan yang isinya berupa peringatan terhadap manusia tentang adanya kehidupan akhirat dengan segala komsekuensinya.

Jadi, dalam komunikasi Nabi Ibrāhim dengan ayahnya beliau menggunakan metode dakwah al-

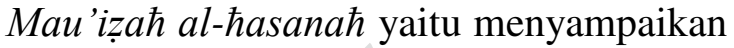
dakwahnya melalui komunikasi lewat nasihat dalam bentuk Tanżir yaitu suatu peringatan namun menggunakan kata yang sopan dan santun.

\section{b. Kisah Nabi Ibrāhim - Ismā'il}

Artinya: "Maka tatkala anak itu sampai (pada umur sanggup) berusaha bersamasama Ibrahim, Ibrahim berkata: "Hai anakku Sesungguhnya aku melihat dalam mimpi bahwa aku menyembelihmu. Maka fikirkanlah apa pendapatmu!" ia menjawab: "Hai bapakku, kerjakanlah apa yang diperintahkan kepadamu; insya Allah kamu akan mendapatiku Termasuk orangorang yang sabar". (Q.S. Q.S. al-Șaffat [37]: 102)

Kisah Nabi Ibrāhim dan Nabi Ismā'il ini menjadi sejarah awal mula di tetapkannya hari raya idul adha yaitu hari raya Qurban. Ujian yang diberikan Allah kepada Nabi Ibrāhim yaitu sebuah mimpi, di dalam mimpi tersebut bahwasannya Nabi Ibrāhim menyembelih Ismā'il anaknya yang selama ini ia harapkan dan dinantikan. Setelah ia mendapatkan mimpi tersebut diceritakanlah mimpi tersebut kepada anaknya Ismā'il, kisah tersebut diabadikan dalam Q.S. al-Ṣaffat [37]: 102105.

Menurut Shihab (2009.c.XI, hal. 280) Dalam Q.S. al-Saffat [37]: 102 Nabi Ibrāhim menyampaikan mimpi itu kepada anaknya. Ini agaknya karena beliau memahami bahwa perintah tersebut tidak dinyatakan sebagai harus memaksanya kepada sang anak. Yang perlu adalah bahwa ia berkehendak melakukannya. 
pesan yang disampaikan Allah melalui mimpinya tersebut kepada Ismā'il anaknya merupakan bentukketaatan Nabi Ibrāhim kepada Allah swt. dalam komunikasi antara Nabi Ibrāhim dan Nabi ismā'il di dalamnya terdapat pesan dakwah yaitu menyampaikan pesan yang Allah perintahkan melalui mimpi seorang Nabi. Dalam dakwah itu terdapat dua dimensi besar salah satunya yaitu mencakup penyampaian pesan kebenaran.

Hal tersebut sejalan dengan pendapat Kusnawan (2009, hal. 16-17) dalam dakwah terdapat dimensi besar yaitu mencakup penyampian pesan kebenaran yaitu dimensi kerisālaћan (bi ahsan alqawl). Dimensi ini mencoba menumbuhkan kesadaran diri dalam (individu/masyarakat) tentang kebenaran nilai dan pandangan hidup secara islami, sehingga terjadi proses internalisasi nilai Islam. Dengan kata lain dakwah kerisālaћan dalam prakteknya merupakan proses mengkomunikasikan nilai-nilai Islam.

Terdapat komunikasi interaktif antara Nabi Ibrāhim dengan anaknya Nabi Ismā'il, karena Nabi Ibrāhim tidak mengambil keputusan sendiri atas permasalahan yang terjadi karena sejatinya dalam komunikasi itu diperlukan untuk mendiskusikan atau memusyawarahkan suatu permasalahan dan meminta pendapat dari lawan bicara agar tidak terjadi suatu perselisihan.

Tindakan Nabi Ibrāhim dalam mendidik anaknya merupakan contoh untuk memberikan kebebasan sendiri kepada anak untuk menentukan pendapatnya. Karena meminta pendapat anak berperan besar dalam menanamkan kepercayaan diri di dalam jiwa anak, membuat anak mengetahui harga dirinya, melatih anak untuk mengaktifkan otaknya dan membangun ide-idenya serta melatih anak untuk mengungkapkan pendapatnya (Al-Hamd, 2011, hal. 94).

Shihab (2009.c.XI, hal. 281) menyatakan ucapan sang anak: (افعل ما تؤمر) if'al mā tu'mar/ laksanakanlah apa yang diperintahkan kepadamu, bukan berkata: "sembelihlah aku", hal tersebut mengisyaratkan sebab kepatuhannya, yakni karena hal tersebut adalah perintah Allah swt. bagaimanapun bentuk, cara, dan kandungan apa yang diperintahkanNya, ia sepenuhnya pasrah.

Nabi Ismā'il merespon pertanyaan dari ayahnya dengan baik, bahwasannya Ismā'il meminta ayahnya untuk melaksanakan apa yang sudah diperintahkan Allah. Dari ayat inilah tergambar komunikasi yang baik antara ayah dan anak dalam menghadapi permasalahan, sehingga keputusan yang diambil pun berdasarkan musyawarah bersama dan kesepakatan kedua belah pihak.

c. Kisah Nabi Ya'qūb-Nabi Yūsuf

Suatu hari datanglah Nabi Yūsuf kepada ayahnya perihal mimpi yang ia dapatkan, dalam Q.S. Yūsuf [12] ayat 4-5 menceritakan mimpi Nabi Yūsuf. Amrullah (1985, hal 170) menyatakan bahwa Nabi Yūsuf langsung menceritakan bahwa ia melihat artinya bermimpi melihat sebelas bintang, dan matahari dan bulan, semuanya bersujud kepadanya.

Ash-Shiddieqy (2000.b.III, hal. 1967) pun menyatakan sebagian ulama berpendapat bahwa yang dimaksud dengan "sebelas bintang" adalah sebelas orang saudara Yūsuf, dan yang dimaksud dengan matahari dan bulan adalah ayah ibunya. Yang dimaksud dengan sujud adalah menundukkan kepala atau semacam memberikan penghormatan.

Lalu dalam ayat selanjutnya pada ayat 5 Nabi Ya'qūb menanggapi cerita mimpi Nabi Yūsuf dan beliau menjelaskan mimpi tersebut, bahwa anak yang disayanginya itu akan memperoleh kedudukan yang besar dan akan memimpin kaumnya, termasuk ayah ibunya, dan saudara-saudaranya. Ya'qūb khawatir, apabila saudara-saudara Yūsuf mengetahui tentang mimpi tersebut, mereka akan dengki dan mencelakakan Yūsuf (ash-Shiddieqy, 2000.b.III, hal. 1967). 
Amrullah (1985, hal. 171) mengemukakan ketegasan beliau dalam melarang Nabi Yūsuf untuk tidak menceritakan mimpinya kepada saudaranya. Jika mereka dengar mimpi tersebut, mereka akan bertambah dengki. Sebab diantara mereka sudah pasti ada yang mengharapkan bahwa merekalah yang akan menerima warisan. Sehingga mereka dapat melakukan tipu daya untuk menyingkirkan Nabi Yūsuf karena sesungguhnya syaitan itu terhadap manusia adalah musuh yang nyata.

Nasihat yang diberikan Nabi Ya'qūb ialah berupa wasiat larangan agar tidak menceritakan mimpinya kepada saudara-saudaranya. Di sini Enjang \&Aliyudin (2009.a, hal. 89) menjelaskan

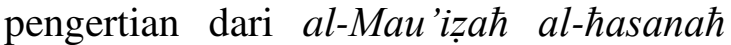
menurut beberapa ahli dan pakar tafsir

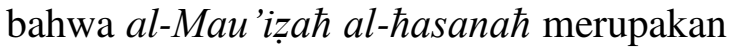
bentuk nasihat, bimbingan, dan arahan untuk kemașlahatan. Dilakukan dengan baik dan penuh tanggung jawab, akrab, komunikatif, mudah dicerna, dan terkesan di hati sanubari.

Jadi, nasihat yang diberikan Nabi Ya'qūb ini merupakan suatu bentuk arahan untuk kemaslahatan, agar Nabi Yūsuf dapat terselamat dari marabahaya yang akan terjadi padanya. Arahan untuk suatu kemaslahatan ini disampaikannya melalui sebuah wasiat.

2. Nilai-Nilai Akhlak Dalam Komunikasi Ayah-Anak di Dalam Al-Quran

a. Kisah Azar - Nabi Ibrāhim

Berikut adalah nilai-nilai akhlak yang muncul dari komunikasi antara Nabi Ibrahim dengan ayahnya:

1) Berkata Halus dan Mulia

Kisah Nabi Ibrāhim dengan ayahnya Azar secara khusus Q.S. Maryam [19]: 42-48 dan Q.S.al-An'ām [6]: 74 menyebutkan peristiwa yang berkaitan dengan keduanya yaitu ketika Nabi Ibrāhim dengan lemah lembut berkata kepada orang tuanya sambil memanggilnya dengan panggilan mesra.
Kata (أبت) abati terambil dari kata (أب)yang dirangkaikan dengan huruf ta yang berfungsi sebagai pengganti huruf (يا) $y \bar{a}$ yang menunjukkan makna kepemilikan. Sehingga abati biasa diartikan ayahku/bapakku. Kata ini mengandung makan kelemah lembutan dan memberi kesan merengek untuk meminta sesuatu kepada orang tua (Shihab, 2008.c.VIII, hal. 195).

Hendaknya dalam menyampaikan pesan dakwah melalui komunikasi menggunakan perkataan yang lembut (Qaulan Layyinan), Allah telah memerintahkan kepada umat manusia untu berkata lemah lembut dalam menyampaikan suatu pesan melalui ayatayatnya di al-Quran.

Selain sang anak yang harus berkata halus dan lembut kepada orang tuanya, sosok orang tua pun hendaknya memberikan teladan yang baik untuk anaknya. Orang tua pun wajib untuk berkata halus dan lembut kepada anaknya ketika mengajak dalam kebenaran upaya tersebut agar seorang yang hatinya keras menjadi lembut.

Sebagaimana Shihab (2008.b.VI. hal. 258) mengungkapkan dalam ayat 42, ayat tersebut menunjukkan betapa naluri manusia begitu cinta kepada anaknya dan anaknya yang durhaka melupakan kebaikan dan ketulusan orang tuanya. Nabi Nūh menyeru anaknya dengan panggilan mesra yaitu (بني) bunayya. Kata bunayya adalah bentuk tasghir/perkecilan dari kata (ابنى)ibnī/anakku. Bentuk itu antara lain digunakan dalam untuk menggambarkan kasih sayang, karena kasih sayang biasanya tercurah kepada anak, apalagi yang masih kecil.

2) Berbuat Baik Kepada Orang Tua Walaupun Keduanya Zalim

Artinya:"Wahai bapakku, Sesungguhnya aku khawatir bahwa kamu akan ditimpa azab dari Tuhan yang Maha pemurah, 
Maka kamu menjadi kawan bagi syaitan". (Q.S. Maryam [19]: 45).

Pada ayat diatas Nabi Ibrahim memperingatkan orang tuanya dengan berkata: "wahai bapakku, sesungguhnya $a k u$ " kata tersebut terdorong oleh rasa cintanya kepada ayahnya dan rasa takutnya Ibrāhim akan azab Allah jika ayahnya sampai tidak bertobat. Kata (أخاف)akhāfu, yakni takut digunakan oleh Nabi Ibrāhim pada ayat ini disamping untuk menampakkan belas kasih dengan menyatakan kekhawatiran jangan sampai orang tuanya itu tersiksa (Shihab, 2008.c.VIII, hal. 198).

Sejalan dengan pendapat A. Mustofa (2005, hal. 168) seorang anak menurut ajaran Islam diwajibkan berbuat baik kepada ibu dan ayahnya, dalam keadaan bagaimanapun. Jangan sampai anak menyinggung perasaan orang tuanya. Jika orang tua berbuat zalim kepada anaknya hendaklah sang anak tidak membalas ketidakbaikkan orang tuanya.

3) Merendahkan diri

¿Artinya:"Wahai bapakku, Sesungguhnya telah datang kepadaku sebahagian ilmu pengetahuan yang tidak datang kepadamu, Maka ikutilah Aku, niscaya aku akan menunjukkan kepadamu jalan yang lurus.(Q.S. Maryam [19]: 43)

Ayat di atas merupakan salah satu perilaku Nabi Ibrāhim dalam merendahkan diri kepada ayahnya, suatu akhlak yang patut di contoh untuk berbakti kepada orang tua. Ash-shieddieqy (2000.b.III, hal. 2482) menyatakan ayat di atas ini memberi suatu pengertian bahwa tanya jawab ini terjadi setelah Ibrāhim diangkat sebagai Nabi. Ibrāhim tidak mengatakan bahwa ayahnya seorang yang bodoh. Dia juga tidak mengatakan bahwa dirinya berilmu yang cukup, melainkan hanya mengatakan dia telah menerima suatu ilmu yang tidak diberikan kepada ayahnya. Dipergunakan cara itu, karena biasanya tidak ada keberatan suatu pun bagi ayah untuk mengikuti anak yang akan menunjukkannya kepada jalan yang lurus.
Ungkapan para mufassir di atas sejalan dengan pendapat Rachman (2012, hal. 88) seorang anak hendaklah merendahkan dirinya di hadapan orang tuanya meskipun sang anak lebih pintar, lebih kaya dan berpengalaman dengan kedudukan yang tinggi di masyarakat.

4) Mendoakan Orang Tua

Dalam Q.S. Maryam [19]: 47 dan 48 Nabi Ibrāhim mendoakan ayahnya yang kafir padahal saat itu dengan tegas orang tuanya mengancam Nabi Ibrāhim. Padahal dalam ayat sebelum yang sudah dijelaskan di atas Nabi Ibrāhim dengan berkata halus dan lembut mengajak dan mengingatkan ayahnya untuk meninggalkan berhala namun dalam Q.S. Maryam [19]: 46 dijelaskan bentuk respon yang buruk dari ayahnya, yang tidak mau mendengarkan dan tidak mau ikut pada ajakan Nabi Ibrāhim.

Amrullah (1983.b.V, hal 42-43) pun mengungkapkan bahwa Ibrahim telah menyambut bantahan ayahnya dengan dada lapang, hormat dan khidmat seorang anak kepada ayah, diucapkannya salam dan dimohonkannya ampun buat beliau. Dia percaya bahwa permohonan ampunannya kepada Tuhan untuk ayahnya niscaya akan dikabulkan Tuhan.

Jelas sudah di atas betapa mulianya Nabi Ibrāhim dalam menyikapi perkataan ayahnya, ia tetap berlaku baik dan mendoakannya ketika ayahnya menolak ajakan Nabi Ibrāhim, padahal ayat sebelumnya telah dijelaskan betapa lembutnya Nabi Ibrāhim dalam bertutur kata. Terlihat pula betapa tingginya akhlak Nabi Ibrāhim kepada tuhannya yaitu dengan ia mempercayai bahwa Allah akan mengabulkan doa beliau. Rasa cinta Nabi Ibrāhim kepada ayahnya telah memperlihatkan ketinggian budi luhur dan akhlaknya bahwa ia mendoakan orang tuanya bagaimanapun keadaan ayahnya. Doa yang ia panjatkan ialah agar Allah dapat memberikan hidayah kepada ayahnya sehingga ayahnya dapat meninggalkan berhal-berhala tersebut. 
b. Kisah Nabi Ibrahim-Nabi Isma'il

1) Mentaati Perintah Allah

Shihab (2009.c.XI, hal. 281) mengungkapkan bahwa Nabi Ismā'il berpendapat atas mimpi ayanya dengan mengatakan (إفعل ما تؤمر) if'al $m \bar{a}$ tu'mar/laksanakanlah apa yang diperintahkan kepadamu Sabar dan rela atas ketetapan Allah, bukan berkata "sembelihlah aku", hal tersebut mengisyaratkan sebab kepatuhannya, yakni karena hal itu merupakan perintah Allah swt. bagaimanapun bentuk, cara, dan kandungan apa yang diperintahkannya ia sepenuhnya pasrah

Sebagaimana pendapat Salamulloh (2008, hal. 4) Ibadah merupakan tunduk dan merendahkan diri yakni taat kepada Allah dengan melaksanakan perintahperintahnya yang disampaikan melalui lisan para Rasul-Nya.

Perilaku dari Nabi Ibrāhim dan Nabi Ismā'il yang taat akan perintah Allah patut dicontoh, hal tersebut menjadi bukti bahwa ketaatan keduanya dalam beribadah untuk mengesakan Allah. Begitu pula Nabi Ibrāhim memberikan teladan yang baik bagi anaknya dengan menaati Allah berarti memberikan contoh kepada anaknya agar ia pun juga dapat mentaati perintah Allah.

\section{2) Sabar dan Rela Atas Ketetapan Allah}

Perkataan Nabi Ismā'il atas pendapatnya ia memerintahkan ayahnya untuk melakukan apa yang sudah di perintahkan Allah, Amrullah (1988, hal 143-144) menyatakan bahwa perkataan Ismā'il -“ya ayahku! Perbuatlah apa yang diperintahkan kepada Engkau. Akan engkau dapati aku- Insya Allah- termasuk orang-orang yang sabar. Alangkah mengharukan sekali jawaban sang anak. Benar-benar terkabul doa ayahnya yang memohon diberi keturunan yang terhitung orang yang șālih.

Perkataan Ismā'il dalam Q.S. alȘaffat [37]: 102 menunjukkan bentuk kesabaran dan kerelaan hatinya atas segala perintah Allah, hal ini menunjukkan tingginya akhlak dan sopan santunnya kepada Allah dan kesabarannya itu pun Ismā'il kaitkan dengan ketetapan Allah.

Ketetapan Allah yang kita kenal sebagai takdir digambarkan oleh dua kata: Qadar dan Qada. Kedua-duanya bermakna ketetapan, tetapi memiliki nuansa yang berbeda. Qadar merupakan makna: ketetapan yang ditentukan sepenuhnya oleh Allah, tanpa bisa diganggu gugat. Sedangkan Qada adalah: ketetapan Allah yang ditentukan berdasarkan usaha tertentu (Mustofa, 2008, hal. 107).

3) Berserah Diri Kepada Allah

Amrullah (1988, hal. 146) menyatakan kunci kejadian dalam Q.S alSaffat [37]terdapat pada ayat 103, yaitu bahwa keduanya-ayah dan anak- aslama berserah diri. Aslamā, yuslimāni, keduanya berserah diri, sebulatnya, sepenuhnya. Itulah Islam! Semuanya terpulang kepada Allah. Dengan sikap penyerahan diri kepada Allah sepenuhnya dan sebulatnya kepada Allah yang demikian itulah sebenar-benarnya agama di sisi Allah.

Begitulah bentuk kesabaran Nabi Ibrāhim dan Nabi Ismā'il menunjukkan bentuk akhlak yang tinggi kepada Allah, karena Allah telah menciptakan manusia dengan sebaik-baiknya ciptaan sehingga manusia patut menyembah dan menyerahkan segalanya kepada Allah karean hakikatnya semua ini merupakan kepunyaan Allah.

Sebagaimana penjelasan di atas bahwasannya merendahkan diri kepada Allah merupakan suatu bentuk Ibadah, agar ibadah dapat diterima, ia harus dilakukan dengan benar. Ibadah tidak dapat dikatakan benar kecuali dengan memenuhi dua syarat berikut: a) ikhlas karena Allah semata, dan terbebas dari syirik besar maupun kecil; dan b) ittiba' (mengikuti) tuntunan Rasūlullaáh saw (Salamulloh, 2008, hal. 6).

c. Kisah Nabi Ya'qūb-Nabi Yūsuf 
Sekian lama Ya'qub dan Yusuf terpisahkan setelah kejadian ketika Yusuf dimasukan ke dalam sumur oleh saudarasudaranya, setelah Yusuf beranjak dewasa Allah pertemukan keduanya kembali lalu Yusuf berkata kepada ayahnya,AshSieddieqy (2000.b.III, hal. 2049) menjelaskan perkataan Nabi Yūsuf dalam QS. Yūsuf: 100 bahwasannya Allah telah berbuat ihsan kepada nya, dan telah mengeluarkannya dari penjara lalu Allah memberikan kedudukan yang tinggi. Nabi Yūsuf pun tidak menyebutkan perbuatan jahat mereka dahulu yang dilakukan terhadap dirinya, dan beliau hanya menyebutkan tentang terlepasnya dia dari penjara yang menjadi batu loncatan menduduki kursi kebesaran.

Jelas dalam QS. Yūsuf: 100 menunjukkan ketinggian budi luhur Nabi Yūsuf kepada orang tuanya dan juga saudara-saudaranya, dengan tidak menceritakan kejahatan saudarasaudaranya karena Nabi Yūsuf tidak ingin memberikan luka kepada ayahnya atas sikap saudara-saudaranya tersebut dan beliau pun menunjukkan bahwa ia telah memaafkan kesalahan saudara-saudaranya yang telah mencelakakannya.

Sebagaimana menurut Munir (2009, hal 257) dalam memberikan informasi yakni menyampaikan pesan hendaknya isi pesan tersebut memberikan berita yang baik dan indah sehingga bisa membuat orang gembira juga untuk menguatkan keimanan sekaligus sebuat harapan dan menjadi motivasi dalam beribadah serta beramal șălih.

3. Implikasi Nilai-Nilai Akhlak Dalam Komunikasi Ayah-Anak Dalam Pembelajaran PAI

\section{a. Pengembangan Komunikasi Edukatif}

Salah satu upaya yang dapat dilakukan oleh seorang pendidik dalam membentuk karakter peserta didik yang berakhlak mulia ialah dengan menjalin komunikasi pembelajaran yang menanamkan nilai-nilai akhlak, komunikasi tersebut terjalin selama proses pembelajaran di dalam kelas. Oleh karena itu, kemampuan komunikasi dalam dunia pendidikan sangat penting. Komunikasi edukatif dapat dikembangkan melalui:

\section{1) Prinsip Kasih Sayang}

Seluruh isi al-Quran tentang pendidikan diwarnai oleh prinsip kasih sayang, Syahidin (2009, hal. 59) menyatakan "pendidikan adalah implementasi dari kasih sayang yang secara fitriah dimiliki setiap orang". Dalam konteks pendidikan, kasih sayang menjadi dasar kokoh bagi komunikasi pendidikan yang terjadi pada pelaksanaan kegiatan belajar mengajar.

2) Prinsip Ketulusan

Bentuk cinta orang tua kepada anaknya dibuktikan dengan ketulusan hati orang tua dalam mendidik, mengasuh, dan membimbing anaknya kepada kebaikan. Ketulusan orang tua dalam mendidik senantiasa tercurahkan tanpa batas waktu. Mendidik anak dengan penuh ketulusan dan rasa ketelatenan yang tinggi mampu membentuk karakter anak secara lebih baik.

\section{3) Prinsip Komunikasi Verbal}

Qaulan sadidan artinya pembicaraan yang benar dan jujur, Qaulan Layyinan berarti pembicaraan yang lemah lembut, aulan Ma'rufan secara etimologis adalah al-Khair atau ihsan, yang berarti baik-baik. Jadi qaulan ma'rufan mengandung pengertian perkataan yang pantas dan baik, Qaulan Karīman yaitu perkataan yang mulia.

\section{b. Pengembangan Sistem Instruksional Pembelajaran}

\section{1) Metode Pembelajaran Edukatif}

Dalam pendidikan Islam, kisahkisah dalam al-Quran mempunyai fungsi edukatif yang sangat berharga dalam suatu proses penanaman nilai-nilai ajaran Islam. Diantara fungsi-fungsi edukatifnya, kisah Qurani dapat dijadikan sebagai bahan pelajaran sekaligus dapat dijadikan sebagai 
metode pengajaran (Syahidin, 2009, hal. 103).

\section{2) Guru Sebagai Role Model}

Guru merupakan sentral figur bagi peserta didik yang memiliki wibawa yang tinggi dan juga mampun untuk menciptakan suasana pembelajaran yang dialogis. Guru menjadi panutan bagi para siswa, maka dari itu keutamaan guru selain mampu mentrasfer pengetahuan guru pun harus menjadi teladan bagi siswanya.

3) Interaksi Pembelajaran Intrapersonal dan Interpersonal

Intrapersonal dan interpersonal keduanya memiliki keterkaitan, komunikasi intrapersonal merupakan pondasi untuk melakukan komunikasi interpersonal. Mampu berdialog dengan diri sendiri berarti mampu mengenal diri sendiri belajar mengenal diri sendiri berarti belajar bagaimana kita berpikir, merasakan, mengamati. Dalam kisah-kisah nabi tentang komunikasi ayah-anak yang sudah dijelaskan sebelumnya menunjukkan adanya komunikasi yang melibatkan para pihak secara emosional dan keakraban diantara keduanya, dan menjadikan komunikasi antara keduanya menjadi harmonis.

\section{KESIMPULAN}

Berdasarkan hasil pembahasan
dapat ditarik kesimpulan bahwa komunikasi ayah-anak yang terdapat dalam kisah Nabi, menurut pandangan para mufasir dalam Tafsir al-Mișbāh, Tafsir al-Azhār, dan Tafsir al-Nūr terhadap kisah Azar-Nabi Ibrāhim dalam Q.S. al-An'ām [6]: 74, Q.S. Maryam [19]: 42-48; kisah Nabi Ibrāhim - Ismā'il dalam Q.S. al-Șâffāt [37]: 102; juga kisah Nabi Ya'qūb - Yūsuf dalam Q.S. Yūsuf [12]: 45, Q.S. Yūsuf [12]: 100 di dalamnya menjelaskan bahwa:

Komunikasi yang terdapat dalam kisah Nabi Ibrāhim dengan ayahnya yang bertentangan tentang suatu kepercayaan akidah dapat menjadi teladan bagi seorang anak agar tetap berbuat baik dan mengingatkan kepada kebenaran. Beruntung apabila orang tua dan anak memiliki kesamaan iman, seperti dalam kisah Nabi Ibrāhim-Ismā'il dan Nabi Ya'qūb-Yūsuf, hal tersebut menjadi contoh ideal orang tua dan anak dalam berkomunikasi. Komunikasi yang ideal inilah mewujudkan komunikasi yang efektif dalam pembelajaran karena di dalamnya terdapat keterbukaan pikiran dan perasaan. Melalui komunikasi, isi pesan yang disampaikan berupaya agar nilai-nilai akhlak dapat terealisasikan.

Dalam pembahasan ini pun dipaparkan nilai-nilai akhlak yang terdapat dalam komunikasi tersebut, terdapat dua ruang lingkup akhlak diantaranya: akhlak kepada Allah dan akhlak kepada sesama manusia. Komunikasi ayah-anak dalam kisah nabi ini terikat dengan perintah agama sebagai bukti ketaatan seorang hamba kepada tuhannya, sehingga pesan yang disampaikan sangat menjunjung tinggi nilai-nilai akhlak dan dalam pembicaraan dengan sesama tidak menyinggung perasaan orang lain.

Kemudian implikasidalam pembelajaran PAI Sebagai pengembangan komunikasi edukatif diantaranya: prinsip kasih-sayang, prinsip ketulusan, dan prinsip komunikasi verbal (Qaulan sadidan, Qaulan layyinan, Qaulan ma'rufan dan Qaulan kariman); dan pengembangan sistem instruksional pembelajaran, diantaranya perlu: metode pembelajaran edukatif, guru sebagai role model, daninteraksi pembelajaran intrapersonal-interpersonal 
Kusnawan, A. (2009). Dimensi Ilmu

Dakwah. Bandung: Widya Padjajaran .

\section{REFERENSI}

A, M. (2005). Akhlak Tasawuf. Bandung: Pustaka Setia.

Al-Hamd, M. b. (2011). Koreksi

Kesalahan Mendidik Anak. (M.

Albani, A. Afifah, Penyunt., \& M.

Muhtadi, Penerj.) Solo: Nabawi

Publishing.

Amrullah, A. M. (1983.b.V). Tafsir AlAzhar Juzu' 13-14-15-16. Jakarta : Pustaka Panjimas.

Amrullah, A. M. (1985). Tafsir Al-Azhar Juzu' 10-11-12. Jakarta: Pustaka Panjimas.

Amrullah, A. M. (1988). Tafsir Al-Azhar Juzu' XXI . Jakarta : Pustaka Panjimas .

Anwar, A. (2009). Ulumul Quran . Pekanbaru : Amzah .

Ash-Shieddieqy, T. M. (2000.b.III). Tafsir Al-Quranul Majid An-Nuur (Surat 11-23) (Vol. III). Semarang: Pustaka Rizki Putra.

Enjang, \& Aliyudin. (2009.a). DasarDasar Ilmu Dakwah. Bandung : Widya Padjajaran .

Gunara, T. (2009). Komunikasi Rasulullah . Bandung : Simbiosa Rekatama Media.

Hermawan, A. (2011). 'Ulumul Quran . Bandung: Rosda .

Jalaluddin. (2011). Psikologi Agama . Jakarta : PT. Raja Grafindo .
M, Q. S. (2008.c. VIII). Tafsir Al-Misbah Pesan, Kesan, dan Keserasian alQuran (Vol. VIII). Tangerang: Lentera Hati.

Munir. (2009). Metode Dakwah. Jakarta : Kencana.

Mustofa, A. (2008). Mengubah Takdir. Surabaya : PADMA Press .

Naim, N. (2011). Dasar-Dasar Komunikasi Pendidikan . Jogjakarta : Ar-Ruzz Media .

Nata, A. (2009). Tafsir ayat-ayat pendidikan. Jakarta : PT Raja Grafindo Persada.

Nata, A. (2009). Tafsir Ayat-Ayat Pendidikan . Jakarta : PT Raja Grafindo.

Rachman, M. F. (2012). Islamic Relationship. Jakarta : Erlangga.

Salamulloh, M. A. (2008). Akhlak Hubungan Vertikal. (F. Rahman, Penyunt.) Yogyakarta: Pustaka Insan Madani.

Saputra, W. (2011). Pengantar Ilmu Dakwah. Jakarta: Raja Grafindo Persada .

Shihab, M. Q. (2008.a.IV). Tafsir AlMisbah pesan, kesan dan keserasian al-Quran (Vol. IV). Tangerang: Lentera Hati.

Shihab, M. Q. (2008.b.VI). Tafsir AlMisabah Pesan, Kesan, dan 
Keserasian al-Quran (Vol. VI).

Tangerang: Lentera Hati.

Shihab, M. Q. (2009.c.XI). Tafsir Al-

Misbah Pesan, Kesan dan

Keserasian al-Quran (Vol. XI).

Tangerang: Lentera Hati.

Sugiyono. (2013). Metode Penelitian

Pendidikan . Bandung : Alfabeta .

Sukmadinata. (2013). Metode Penelitian

Kualitatif . Bandung: Remaja

Rosdakarya.

Suryabrata, S. (2012). Metodologi

Penelitian. Jakarta: Rajawali Pers.

Syahidin. (2009). Menelusuri Metode

Pendidikan dalam Al-Quran.

Bandung: Alfabeta .

Yusuf, K. M. (2012). Studi Al-Quran. Jakarta: Amzah. 